\title{
Venom-Induced Consumption Coagulopathy Following Hump-Nosed Pit Viper (Genus: Hypnale) Envenoming in Sri Lanka: Uncertain Efficacy of Fresh Frozen Plasma
}

\author{
R.M.M.K. Namal Rathnayaka, MBBS, MPhil, MA, MSc in Medical Tox., Dip. in Tox., Dip. in OH\& $\mathrm{S}^{1,2,3}$; \\ P.E. Anusha Nishanthi Ranathunga, $\mathrm{MBBS}^{4}$; S.A.M. Kularatne, MBBS, MD, MRCP (UK), FRCP (Lond) ${ }^{5}$ \\ ${ }^{1}$ Department of Veterinary Pathobiology, Faculty of Veterinary Medicine and Animal Science, University of Peradeniya, Peredeniya, Sri Lanka; ${ }^{2}$ Inten- \\ sive Care Unit/Anaesthesia, Teaching Hospital Ratnapura, Sri Lanka; ${ }^{3}$ Postgraduate Institute of Medicine (Clinical Pharmacology and Therapeutics), \\ University of Colombo, Colombo, Sri Lanka; ${ }^{4}$ Medical Unit, Teaching Hospital Ratnapura, Sri Lanka; ${ }^{5}$ Faculty of Medicine, University of Peradeniya, \\ Peredeniya, Sri Lanka
}

\begin{abstract}
Introduction-Hump-nosed pit vipers (Hypnale spp) cause the highest number of venomous snakebites in Sri Lanka. Bites commonly cause local envenoming leading to local pain, swelling, and necrosis of the site of the bite. Acute kidney injury is the most common systemic manifestation, and some patients develop venom-induced consumption coagulopathy (VICC). Genus Hypnale comprises 3 species. Of them, $H$ hypnale is found in Sri Lanka and the Western Ghats region of India. The other 2 (H nepa and H zara) are endemic species in Sri Lanka.

Methods - This study included 500 patients with hump-nosed viper bites studied prospectively over 4.5 y starting June 2014. All patients were assessed and the data were collected by the principal investigator (primary data). A subgroup of patients who developed VICC is described. There were 2 groups, including proven (patients with the specimen of the snake) and probable (specimen of snake not available) bites.

Results-Thirty ( $\mathrm{n}=500 ; 6 \%)$ patients developed VICC; of them, $17(3 \%)$ were proven cases, and 13 $(2 \%)$ were probable cases. In both groups, $24(80 \%)$ recovered, $2(7 \%)$ progressed to chronic kidney disease, $1(3 \%)$ died of severe hemostatic dysfunction, and $3(10 \%)$ were lost to follow-up. Systemic bleeding was observed in 16 patients (53\%), including hematuria (microscopic and gross) in 8 (27\%) and venipuncture bleeding in $5(17 \%)$. Eleven (37\%) developed local bleeding at the site of the bite. Fresh frozen plasma was administered to 20 patients $(67 \%)$, among whom only $11(55 \%)$ experienced early correction of VICC. In both groups, 15 (50\%) developed acute kidney injury, and $2(7 \%)$ progressed to chronic kidney disease. Microangiopathic hemolysis was observed in 18 patients $(60 \%)$ and thrombocytopenia in 16 $(53 \%)$. Thrombotic microangiopathy was detected in 13 patients $(43 \%)$, of whom $10(33 \%)$ developed hemolytic uremic syndrome and $2(7 \%)$ had thrombotic thrombocytopenic purpura. Of patients with VICC in the proven group, 94\% ( $\mathrm{n}=16)$ was caused by $H$ hypnale and $1(6 \%)$ was caused by $H$ zara. In the proven group, median international normalized ratio was 3.7 (interquartile range 1.6-5.0); in the probable group, it was 5.0 (interquartile range 2.1-5.4).

Conclusions-We found that $6 \%$ of patients develop hemostatic dysfunction after hump-nosed viper bites. However, which patients will develop coagulopathy or die of envenoming is unpredictable. Reliable and accessible treatments are unmet essential needs because antivenoms for these bites are currently not available in the country. Therapy with fresh frozen plasma has doubtful efficacy in early correction of VICC and needs further evaluation.
\end{abstract}

Keywords: snakebites, thrombotic microangiopathy, Hypnale zara, Hypnale nepa, WBCT20

Corresponding author: R.M.M.K. Namal Rathnayaka, MBBS, MPhil, MA, MSc in Medical Tox, Dip. in Tox, Dip in OH\&S, PhD Candidate, Department of Veterinary Pathobiology, Faculty of Veterinary Medicine and Animal Science, University of Peradeniya, Sri Lanka, No. 11, Flower Road, New Town Housing Scheme 01, New Town, Ratnapura, Sri Lanka. 099714337784; e-mail: namalrath10@yahoo.com.

Submitted for publication May 2019.

Accepted for publication December 2019. 


\section{Introduction}

Hump-nosed pit vipers (Hypnale spp), although small at $<600 \mathrm{~mm}$ in total length, are venomous and belong to category I in the World Health Organization classification, ${ }^{1}$ which often requires antivenom. Their bites cause unpredictable significant morbidity and mortality. ${ }^{2-4}$ Hypnale spp. are the most common cause of venomous snakebites in Sri Lanka, ${ }^{5}$ accounting for 22 to $77 \%$ of all snakebites. ${ }^{6}$

Genus Hypnale comprises 3 species: H hypnale, H zara, and $H$ nepa. The former is found in both Sri Lanka and the Western Ghats region of India, and the latter 2 are endemic to Sri Lanka. ${ }^{7}$ The spectrum of clinical profile in Hypnale envenoming differs greatly, from dry bites to severe envenoming including venom-induced consumption coagulopathy (VICC), acute kidney injury (AKI), and even chronic kidney disease (CKD). Although local envenoming occurs more frequently after Hypnale bites, ${ }^{8-11}$ systemic effects such as AKI, CKD,${ }^{12,13}$ VICC, ${ }^{2,14-16}$ thrombotic microangiopathy (TMA), ${ }^{13,17,18}$ ischemic strokes,${ }^{19}$ myocardial infarction, atrial fibrillation, and cardiac arrest ${ }^{4,20}$ have also been reported. Of the 3 species, H hypnale Ho,11, 16,21 $^{10}$ and $H z_{z a r a}^{2,11,18}$ cause VICC, but such complications have not so far been reported after $H$ nepa bites.
There are 2 principal pattern of coagulopathy in snake envenomation: procoagulation (defibrination) and anticoagulation. Viperid snakes, most Australian elapids, and some non-front-fanged snakes cause VICC associated with local and systemic bleeding. VICC is the most common coagulopathy caused by snake envenoming worldwide and results from activation of the coagulation pathway by procoagulant toxins in snake venom [thrombin-like enzymes (TLEs), prothrombin activators, factor V, VII, X activators, and plasminogen activators] or consumption of fibrinogen. Procoagulants are classified under snake hemotoxins, along with anticoagulants, platelet toxins, and hemorrhagins. ${ }^{22}$ Venom of $H$ hypnale is procoagulant and fibrinolytic in vitro ${ }^{23}$ and causes mild or incomplete coagulopathy that is hypothesized to be due to TLEs. ${ }^{24}$

\section{Methods}

Ethical approval for the study was obtained from the faculty of medicine, University of Peradeniya, Sri Lanka. Written consent for publication of photographs was obtained from individual patients. This prospective observational hospital-based clinical study commenced in June 2014 and was carried out over $4.5 \mathrm{y}$ in medical wards at the Teaching Hospital, Ratnapura (THR), Sri Lanka.
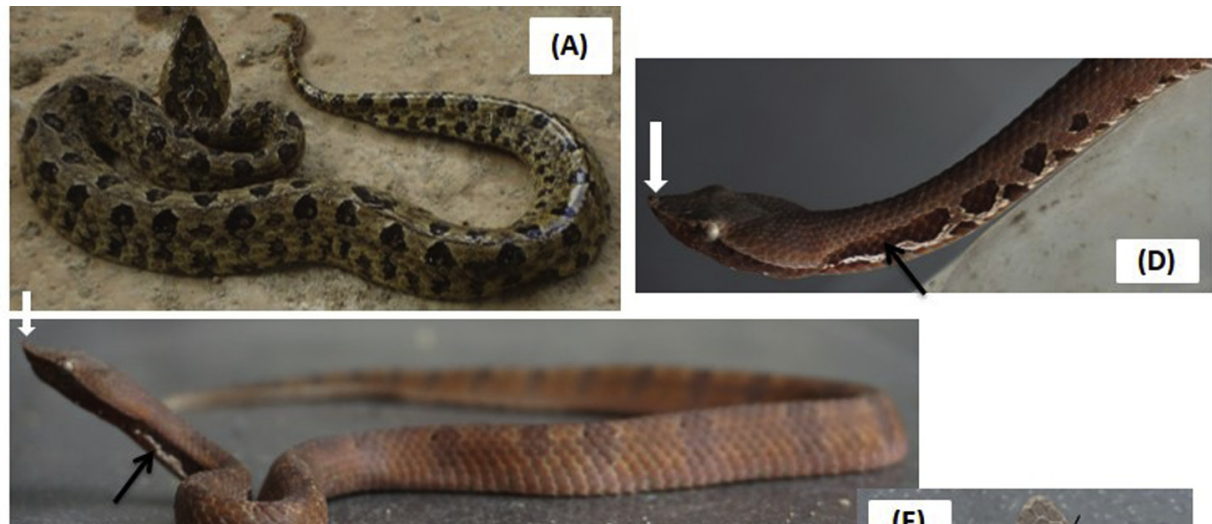

(B)

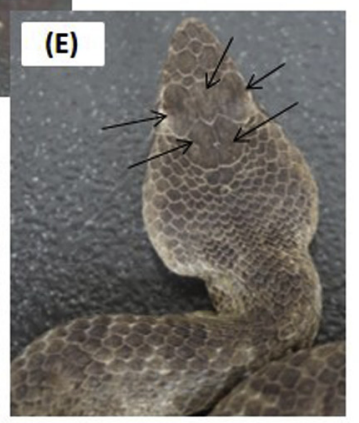

Figure 1. Three species of genus Hypnale: (A) H hypnale from Ratnapura ( $06^{\circ} 40^{\prime} \mathrm{N} 80^{\circ} 24^{\prime} \mathrm{E}$, elevation $130 \mathrm{~m}$ [430 ft]), (B) $H$ zara from Ratnapura

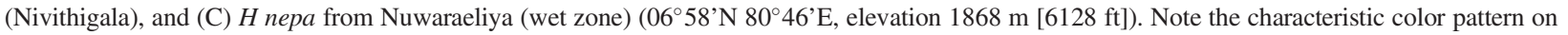
the neck (indicated in a thick black arrow) and prominent "hump" (indicated in a white arrow) of $H$ zara and (D) the characteristic 5 large head scales of genus Hypnale (indicated in thin black arrows in E). 
All patients with hump-nosed viper bites were included in the study. On admission, the patients were assessed by the corresponding author and reassessed every $12 \mathrm{~h}$ until hospital discharge. Epidemiological information, clinical manifestations, investigations, treatments, and outcomes were recorded in a formatted data sheet. Local envenoming effects such as pain, swelling, bleeding, necrosis, and lymph node enlargement were assessed. Coagulopathy was assessed in the presence of bleeding manifestations, 20-min whole blood clotting test (WBCT20), and clotting profile (prothrombin time/international normalized ratio [PT/INR], activated partial thromboplastin time [APTT]). The cut-off values for PT, INR, and APTT were 10 to $15 \mathrm{~s}, 1$ to 1.4 , and 25 to 30 $\mathrm{s}$, respectively. The following methods were used to identify the offending snake as the hump-nosed pit viper:

1. When live or dead specimens of offending snakes were available, they were identified by the corresponding author using a standard key. ${ }^{7}$ These patients were categorized as proven (confirmed) hump-nosed viper bite cases.

2. When specimens were not available, the patients or the witnesses were shown formalin-preserved snakes and color plates of the snakes to determine the offending snake. Thus, identification of the snake was based on circumstantial evidence, mainly the description given by eyewitnesses. These patients were categorized as probable (suspected) cases.

The morphological characteristics of all snakes, such as sex, head length, tail length, snout to vent length, total length, and scale counts, were recorded. Dead specimens were preserved in $10 \%$ formalin and labeled with the patient's serial number and the date of admission. Dead specimens were deposited at THR, Sri Lanka, and live snakes were digitally photographed to confirm identification and released to their natural habitat.

\section{Results}

\section{SNAKE IDENTIFICATION}

There were 30 patients $(6 \%)$ with coagulopathy. Of them, $17(57 \%)$ brought the responsible snake to the hospital; all snakes were killed. Of 17 specimens, 16 (94\%) were $H$ hypnale, and $1(6 \%)$ were $H$ zara. All patients were bitten in catchment areas of Ratnapura district in wet zone of Sri Lanka that all 3 species of genus Hypnale inhabit. Morphological differentiation of these 3 species of hump-nosed vipers is difficult because they all look alike to the naked eye (Figure 1). The "hump" is the key identifying feature of these snakes: $H$ zara has a prominent hump (Figure 1B and 1D), whereas the other 2 species do not have a clearly visible hump. Keeled costal scales are found in both $H$ hypnale and $H$ zara, whereas $H$ nepa has smooth costal scales. There are 2 types of pit viper in Sri Lanka, including humpnosed vipers and Green pit vipers. Hump-nosed vipers have 5 large head scales (Figure 1E), whereas Green pit vipers have small head scales.

\section{EPIDEMIOLOGY}

The demographic and epidemiological data are shown in Table 1. During the study period, there were 1454 patients with snakebites, of which hump-nosed vipers were responsible for $500(34 \%)$. In total, 384 bites $(77 \%)$ were proven hump-nosed viper bites and $116(23 \%)$ were probable bites. Of the 500 patients with hump-nosed viper bites, 30 patients $(6 \%)$ patients had coagulopathy. In the proven group, $11(65 \%)$ were males and $6(35 \%)$ were females. Their mean age was 54.5 y (range 33-74 y). Eleven $(65 \%)$ were bitten during the day $(0600-1759)$ whereas 6 (35\%) were bitten at night (1800-0559). Twelve (71\%) were bitten on lower limbs: feet in $11(65 \%)$ and toes in 1 (6\%) patient. In 5 patients (29\%), bites occurred to upper limbs: hands in $3(18 \%)$ and fingers in $2(12 \%)$. In the proven group, most of the bites occurred on tea estates $(n=6$; $35 \%)$, followed by home gardens $(n=5 ; 29 \%)$ and footpaths $(n=3 ; 18 \%)$. The occupations of patients were manual laborer $(n=3 ; 18 \%)$, farmer $(n=2 ; 12 \%)$, and tea leaf plucker $(\mathrm{n}=2 ; 12 \%)$. The education levels were grade $<5(\mathrm{n}=7$; $41 \%)$, between grade 5 and $11(\mathrm{n}=6 ; 35 \%)$, and up to ordinary level examination $(\mathrm{n}=4 ; 24 \%)$. Fourteen patients $(82 \%)$ received some form of first aid measure (ligation $[n=10$; $59 \%]$ and washing the bite site $[\mathrm{n}=9 ; 53 \%])$ before admission to hospital. Three patients (18\%) had ingested curry leaf (Murraya koenigii "Karapincha") broth; of them, 2 (12\%) had visited a native physician (Vedamahattaya) for herbal medicines. Most of the bites $(n=14 ; 82 \%)$ occurred without provocation. Duration of hospital stay was 3 to 20 $\mathrm{d}$ (median $4 \mathrm{~d}$, interquartile range [IQR] 4-12.5 d) in the proven group and 3 to $28 \mathrm{~d}$ (median $8 \mathrm{~d}$, IQR $4-18 \mathrm{~d}$ ) in the probable group. Three patients $(10 \%)$ in both groups left against medical advice.

\section{CLINICAL PROFILE}

Clinical manifestations of proven and probable cases are shown in Table 2. Of the 30 patients with VICC, all (100\%) showed local envenoming symptoms. In 17 of the proven group, local pain was assessed as mild $(\mathrm{n}=1 ; 6 \%)$, moderate $(\mathrm{n}=4 ; 24 \%)$, and severe $(\mathrm{n}=12 ; 70 \%)$. Local swelling was also graded mild $(n=2 ; 12 \%)$, moderate $(n=6$; $35 \%)$, and severe $(n=9 ; 53 \%)$. Other local manifestations were bleeding $(n=7 ; 41 \%)$, blistering $(n=4 ; 24 \%)$, lymphadenopathy $(n=4 ; 24 \%)$, necrosis at the site of the bite, and 
bruising (each $n=2 ; 12 \%)$. Eight $(47 \%)$ of the proven group had nonspecific symptoms such as nausea, vomiting, abdominal pain, and headache. All patients in this cohort had systemic envenoming symptoms manifest as VICC. In the proven group, AKI was observed in 8 patients (47\%), 2 of whom developed CKD. Microangiopathic hemolysis was found in $10(59 \%)$ and thrombocytopenia in 9 (53\%) patients. Six (35\%) developed TMA, 4 of whom (24\%) had hemolytic uremic syndrome and 2 (12\%) had thrombotic thrombocytopenic purpura.

\section{COAGULOPATHY AND BLEEDING MANIFESTATIONS}

Out of $30(6 \%)$ patients with VICC, $17(3 \%)$ were in the proven group and $13(2 \%)$ were in the probable group. In the proven group, onset of coagulopathy ranged from $1 \mathrm{~h}$ to $120 \mathrm{~h}$ after the snakebite (median $3.5 \mathrm{~h}$; IQR 2-18 h; mode $2 \mathrm{~h}$ ) (Table 3), whereas it was $45 \mathrm{~min}$ to $24 \mathrm{~h}$ (median $3 \mathrm{~h}$; IQR $1-24 \mathrm{~h}$; mode $1 \mathrm{~h}$ ) in the probable group (Table 4) as detected from WBCT20 and clotting profile. Coagulopathy lasted 1 to $8 \mathrm{~d}$ (mean $3.0 \mathrm{~d}$; SD $1.9 \mathrm{~d}$; mode $1 \mathrm{~d}$ ) in the proven group and $8 \mathrm{~h}$ to $9 \mathrm{~d}$ (mean $3.2 \mathrm{~d}$; SD $2.5 \mathrm{~d}$; mode 1 day) in the probable group. Eleven patients (38\%) had local bleeding (Figure 2) on admission, 7 (41\%) of whom were in the proven group and $4(31 \%)$ in the probable group. In the proven group, hematuria (both microscopic and gross) was observed in $6(35 \%), 5(29 \%)$ of whom developed gross hematuria and 6 developed microscopic hematuria. In the probable group, microscopic hematuria was found in 2 (15\%), but macroscopic hematuria was not detected. Of 30 patients with VICC, systemic bleeding occurred in 8 $(27 \%), 5(29 \%)$ in the proven group and $3(23 \%)$ in the probable group.

In the proven group, 3 (18\%) had bleeding from canula sites, 1 (S.No. 293) developed generalized ecchymoses (Figure 3), ${ }^{21}$ and another (S.No. 500) had gross hematuria and rectal, gum, and pulmonary hemorrhages. The latter patient died of severe systemic bleeding associated with VICC. ${ }^{25}$ In the patient's postmortem examination, pericardial, endocardial, pulmonary, cerebral, and cerebellar hemorrhages were noted, as was bleeding into the thoracic cavity. Petechial hemorrhage in kidneys, lungs, gray and white mater of cerebrum, and midbrain were also noted (Figure 4). S.No. 364 patient in the probable group had bilateral subconjunctival hemorrhages that appeared on day 2 (Figure 5) and disappeared on day 26 after humpnosed viper bite.

\section{LABORATORY FINDINGS}

Coagulopathy was detected using WBCT20 and clotting profile (PT, INR, and APTT). Twenty-nine patients (6\%) did not have clotted blood on WBCT20 (>20 min); 16 (4\%) were in the proven group and $13(11 \%)$ were in the probable group. Clotted blood on WBCT20 (<20 min) was detected in 1 patient in the proven group (S.No. 363), but his clotting profile was prolonged and therefore, VICC was established. Two patients in the proven group (S.No. 337 and 378) were found to have a normal clotting profile, but their blood was not clotted in WBCT20 for $1 \mathrm{~d}$ duration. Of these 2, 1 had gross hematuria and the other had no clinical bleeding.

In both groups, 27 (5\%) had prolonged PT and INR, whereas $28(6 \%)$ had elevated APTT. In the proven group, PT was unrecordable ( $>60 / 12$ s) initially in 10 patients (59\%) and APTT was $>60 / 25 \mathrm{~s}$ in 10 patients (59\%). H nepa bites did not elevate PT, INR, APTT, or WBCT20. $H$ zara caused elevation of clotting tests in 1 patient (3\%), whereas PT, INR, and APTT were high in $14(5 \%)$ and WBCT20 was positive in 15 patients $(5 \%)$ with $H$ hypnale bites. For 2 patients (S.No. 474 and 500) who developed pesistently incoagulable blood, we performed rotational thromboelastometry after administering fresh frozen plasma (FFP) and found a very low level of fibrinogen and other clotting factors. In the proven group, median INR was 3.7 (IQR 1.6-5.0); in the probable group, it was 5 (IQR 2.1-5.4). Although FFP was administered to 20 patients $(67 \%)$, only $11(55 \%)$ had early correction of VICC within 1 to 2 days; in 9 cases (45\%), clotting profile fluctuated further and there was no early correction of VICC.

\section{TREATMENTS}

It was our routine practice to treat with FFP those patients who had persistent incoagulable blood (unclotted blood in WBCT20) associated with clinical bleeding. FFP was administered usually as 2 packs twice daily (10 $\mathrm{mL} \cdot \mathrm{kg}^{-1}$ ) for 3 days. Accordingly, 20 patients $(67 \%)$ were given FFP, $11(65 \%)$ in the proven group and 9 $(69 \%)$ in the probable group. Local pain was treated with paracetamol $1 \mathrm{~g}$ thrice a day and tramadol $50 \mathrm{mg}$ twice a day in severe cases. Local swelling was relieved with elevation of the affected limb; if cellulitis was suspected, intravenous or oral cloxacillin $500 \mathrm{mg}$ every $6 \mathrm{~h}$ and oral metronidazole $400 \mathrm{mg}$ every $8 \mathrm{~h}$ were given. Patients who had severe local swelling were closely monitored for assessment of compartment syndrome by distal pulse, oxygen saturation indicated by pulse oximetry $\left(\mathrm{S}_{\mathrm{p}} \mathrm{O}_{2}\right)$, and capillary refilling time of the affected limb. Wound debridement was performed for patients with local tissue necrosis and blistering at the site of the bite. Fluid intake and output was maintained with monitoring of renal function tests. Hemodialysis was 
Table 1. Epidemiology of 30 patients with coagulopathy (VICC) after hump-nosed pit viper (Hypnale spp) envenoming

\begin{tabular}{|c|c|c|}
\hline Epidemiological features & Proven cases $(n=17)$ & Probable cases $(n=13)$ \\
\hline Age (y) (range, mean) & $33-74,54.5$ & $23-60,43.2$ \\
\hline \multicolumn{3}{|l|}{$\operatorname{Sex}[n(\%)]$} \\
\hline Male & $11(65)$ & $7(54)$ \\
\hline Female & $6(35)$ & $6(46)$ \\
\hline \multicolumn{3}{|l|}{ Time of bite [n (\%)] } \\
\hline Day (0600-1759) & $11(65)$ & $8(61.5)$ \\
\hline Night (1800-0559) & $6(35)$ & $5(38.5)$ \\
\hline \multicolumn{3}{|l|}{ Site of bite $[\mathrm{n}(\%)]$} \\
\hline Feet & $11(65)$ & $6(47)$ \\
\hline Hands & $3(18)$ & - \\
\hline Fingers & $2(12)$ & $2(15)$ \\
\hline Toes & $1(6)$ & $2(15)$ \\
\hline Ankles & - & $2(15)$ \\
\hline Leg & - & $1(8)$ \\
\hline \multicolumn{3}{|l|}{ Place of bite [n (\%)] } \\
\hline Tea estates & $6(35)$ & $5(39)$ \\
\hline Home garden & $5(29)$ & $2(15)$ \\
\hline Foot path & $3(18)$ & $2(15)$ \\
\hline Rubber estates & $1(6)$ & - \\
\hline Pepper estates & $1(6)$ & $1(8)$ \\
\hline Concrete roads & $1(6)$ & $1(8)$ \\
\hline Tarry road & - & $2(15)$ \\
\hline \multicolumn{3}{|l|}{ Occupation $[\mathrm{n}(\%)]$} \\
\hline None & $6(35)$ & $1(8)$ \\
\hline Manual laborer & $3(18)$ & $2(15)$ \\
\hline Farmer & $2(12)$ & $2(15)$ \\
\hline Tea leaf plucker & $2(12)$ & $3(23)$ \\
\hline Gem miner & $1(6)$ & - \\
\hline Mason & $1(6)$ & - \\
\hline Hotel owner & - & $2(15)$ \\
\hline Estate worker & - & $1(8)$ \\
\hline Other & - & $2(15)$ \\
\hline \multicolumn{3}{|l|}{ Education $[\mathrm{n}(\%)]$} \\
\hline Grade $<5$ & $7(41)$ & $3(23)$ \\
\hline Grade $5-11$ & $6(35)$ & $3(23)$ \\
\hline Up to ordinary level examination & $4(24)$ & $3(23)$ \\
\hline Up to advanced level examination & - & $2(15)$ \\
\hline None & - & $2(15)$ \\
\hline \multicolumn{3}{|l|}{ First aid measures $[\mathrm{n}(\%)]$} \\
\hline None & $3(18)$ & $4(33)$ \\
\hline Ligation & $10(59)$ & $7(54)$ \\
\hline Washing site of bite & $9(53)$ & $7(54)$ \\
\hline \multicolumn{3}{|l|}{ Provocation $[\mathrm{n}(\%)]$} \\
\hline No & $14(82)$ & $11(85)$ \\
\hline Yes & $3(18)$ & $2(15)$ \\
\hline \multicolumn{3}{|l|}{ Native treatments $[\mathrm{n}(\%)]$} \\
\hline No & $15(88)$ & $8(62)$ \\
\hline Yes & $2(12)$ & $5(38)$ \\
\hline Ingestion of curry leaf (Murraya koenigii) broth & $3(18)$ & $5(42)$ \\
\hline \multicolumn{3}{|l|}{ Hospitalization } \\
\hline Time to hospital admission after the snakebite & $15 \min -4 \mathrm{~d}$ & $40 \min -2 \mathrm{~d}$ \\
\hline Transfer to National Hospital Sri Lanka [n (\%)] & $2(12)$ & - \\
\hline Duration of hospital stay (d) & $3-20$ & $3-28$ \\
\hline Left against medical advice [n (\%)] & $2(12)$ & $1(8)$ \\
\hline
\end{tabular}


Table 2. Clinical profile of 30 patients with coagulopathy after hump-nosed pit viper (Hypnale spp) envenoming

\begin{tabular}{|c|c|c|}
\hline \multirow[t]{2}{*}{ Clinical manifestations } & \multirow{2}{*}{$\frac{\text { Proven cases }(n=17)}{n(\%)}$} & \multirow{2}{*}{$\frac{\text { Probable cases }(n=13)}{n(\%)}$} \\
\hline & & \\
\hline \multicolumn{3}{|l|}{ Local envenoming } \\
\hline \multicolumn{3}{|l|}{ Pain: } \\
\hline Mild & $1(6)$ & $4(31)$ \\
\hline Moderate & $4(24)$ & $2(15)$ \\
\hline Severe & $12(70)$ & $7(54)$ \\
\hline \multicolumn{3}{|l|}{ Swelling: } \\
\hline Mild & $2(12)$ & $3(23)$ \\
\hline Moderate & $6(35)$ & $5(39)$ \\
\hline Severe & $9(53)$ & $5(39)$ \\
\hline Local bleeding & $7(41)$ & $4(31)$ \\
\hline Blistering & $4(24)$ & $2(15)$ \\
\hline Lymphadenopathy & $4(24)$ & $2(15)$ \\
\hline Necrosis at site of bite & $2(12)$ & $2(15)$ \\
\hline Bruising & $2(12)$ & $2(15)$ \\
\hline \multicolumn{3}{|l|}{ Systemic envenoming } \\
\hline Coagulopathy & $17(100)$ & $13(100)$ \\
\hline Acute kidney injury & $8(47)$ & $7(54)$ \\
\hline Chronic kidney disease & $2(12)$ & - \\
\hline Microangiopathic hemolysis & $10(59)$ & $\overline{8}(62)$ \\
\hline Thrombotic microangiopathy & $6(35)$ & $7(54)$ \\
\hline Hemolytic uremic syndrome & $4(24)$ & $6(47)$ \\
\hline Thrombotic thrombocytopenic purpura & $2(12)$ & - \\
\hline Thrombocytopenia & $9(53)$ & $7(54)$ \\
\hline Systemic bleeding & $6(35)$ & $2(15)$ \\
\hline Hematuria & $5(29)$ & - \\
\hline Macroscopic & $5(29)$ & - \\
\hline Microscopic & $6(35)$ & $2(15)$ \\
\hline Bleeding from canula sites & $3(18)$ & $2(15)$ \\
\hline Generalized ecchymoses & $1(6)$ & - \\
\hline Pulmonary hemorrhages & $1(6)$ & - \\
\hline Gum bleeding & $1(6)$ & - \\
\hline Rectal bleeding & $1(6)$ & - \\
\hline Subconjunctival hemorrhages & - & $1(8)$ \\
\hline Nonspecific manifestations & $8(47)$ & $4(31)$ \\
\hline Nausea & $5(29)$ & $2(15)$ \\
\hline Vomiting & $6(35)$ & $3(23)$ \\
\hline Abdominal pain & $5(29)$ & $1(8)$ \\
\hline Headache & $2(12)$ & $1(8)$ \\
\hline Faintness & $6(35)$ & $1(8)$ \\
\hline Fever & $1(6)$ & - \\
\hline \multicolumn{3}{|l|}{ Complications } \\
\hline Myalgia & $14(82)$ & $4(31)$ \\
\hline Cellulitis & $3(19)$ & $2(15)$ \\
\hline Urinary tract infections & - & $1(8)$ \\
\hline \multicolumn{3}{|l|}{ Treatments } \\
\hline Administration of fresh frozen plasma & $11(65)$ & $9(69)$ \\
\hline Hemodialysis & $6(35)$ & $6(47)$ \\
\hline Therapeutic plasma exchange & $2(12)$ & $4(31)$ \\
\hline Wound toilet & $4(24)$ & $1(8)$ \\
\hline \multicolumn{3}{|l|}{ Outcome } \\
\hline Recovered & $12(71)$ & $12(92)$ \\
\hline Not recovered (chronic kidney disease and death) & $3(19)$ & - \\
\hline Died & $1(6)$ & - \\
\hline Lost to follow-up & $2(12)$ & $1(8)$ \\
\hline
\end{tabular}


Table 3. Hematological parameters of 17 patients with proven hump-nosed pit viper (H hypnale and $H$ zara) envenoming

\begin{tabular}{|c|c|c|c|c|c|c|c|c|c|c|c|c|}
\hline $\begin{array}{l}\text { Patient } \\
\text { serial no. }\end{array}$ & $\begin{array}{l}\text { Onset of } \\
\text { VICC } \\
\text { after } \\
\text { snakebite }\end{array}$ & $\begin{array}{l}\text { End of } \\
\text { VICC } \\
\text { after } \\
\text { snakebite }\end{array}$ & WBCT20 & $\begin{array}{l}\text { Highest } \\
P T(s)\end{array}$ & $\begin{array}{l}\text { Highest } \\
\text { INR }\end{array}$ & $\begin{array}{l}\text { Highest } \\
\operatorname{APTT}(s)\end{array}$ & $\begin{array}{l}\text { Lowest } \\
\text { platelet } \\
\text { count } \\
\left(\times 10^{3} \cdot \mu L^{-1}\right)\end{array}$ & $\begin{array}{l}\text { Lowest } \\
H b \\
\left(g \cdot d L^{-1}\right)\end{array}$ & Clinical bleeding & $\begin{array}{l}\text { Administration } \\
\text { of FFP }\end{array}$ & МАHА & $T M A$ \\
\hline 12 & $15 \mathrm{~h}$ at $\mathrm{LH}$ & $5 \mathrm{~d}$ & Positive & $>60 / 12$ at $\mathrm{D} 2$ & $>5.4$ at $\mathrm{D} 2$ & $40 / 25$ at $\mathrm{D} 2$ & 163 at $\mathrm{D} 2$ & 7.1 at D5 & Hematuria & $\begin{array}{l}\text { Yes-1 pack } \\
\text { at D2 }\end{array}$ & Yes & No \\
\hline 53 & $1 \mathrm{~h}$ at $\mathrm{LH}$ & $2 \mathrm{~d}$ & Positive & $>60 / 12$ at $\mathrm{D} 2$ & $>5.9$ at $\mathrm{D} 2$ & $>60 / 25$ at $\mathrm{D} 2$ & 228 at D2 & 12.4 at D2 & Local bleeding & No & No & No \\
\hline 278 & $2 \mathrm{~h}$ at $\mathrm{LH}$ & $1 \mathrm{~d}$ & Positive & $22.5 / 12$ at D1 & 1.9 at D1 & $40 / 25$ at D1 & 212 at D3 & 9.5 at D4 & No & No & No & No \\
\hline 284 & $\begin{array}{l}5 \mathrm{~h} \text { on } \\
\text { admission }\end{array}$ & $3 \mathrm{~d}$ & Positive & $>120 / 12$ at D2 & $>10$ at $\mathrm{D} 2$ & $>60 / 25$ at $\mathrm{D} 2$ & 168 at D3 & 10.3 at D3 & No & No & No & No \\
\hline 293 & $3 \mathrm{~h}$ at $\mathrm{LH}$ & $5 \mathrm{~d}$ & Positive & $34 / 12$ at D4 & 2.9 at $\mathrm{D} 4$ & $40 / 25$ at D4 & 158 at D3 & 6.5 at D2 & $\begin{array}{l}\text { Bleeding from } \\
\text { venipunctures, } \\
\text { ecchymoses }\end{array}$ & $\begin{array}{l}\text { Yes-3 packs at } \\
\text { D1 and D2 }\end{array}$ & Yes & No \\
\hline 337 & $\begin{array}{l}2.5 \mathrm{~h} \text { on } \\
\text { admission }\end{array}$ & $1 \mathrm{~d}$ & Positive & $13 / 12$ at $\mathrm{D} 2$ & 1.1 at D2 & $24 / 25$ at D2 & 209 at D1 & 12.8 at D1 & Hematuria & No & No & No \\
\hline 351 & $\begin{array}{l}2 \mathrm{~h} \text { on } \\
\text { admission }\end{array}$ & $2 \mathrm{~d}$ & Positive & $>60 / 12$ at $\mathrm{D} 1$ & $>5$ at $\mathrm{D} 1$ & $>60 / 25$ at $\mathrm{D} 1$ & 201 at D1 & 13.2 at D1 & Local bleeding & No & No & No \\
\hline 363 & $\begin{array}{l}120 \mathrm{~h} \text { at } \\
\text { medical } \\
\text { ward }\end{array}$ & $1 \mathrm{~d}$ & Negative & $25 / 12$ at D6 & 2.1 at D6 & $90 / 25$ at D6 & 65 at D4 & 6.4 at D5 & Local bleeding & $\begin{array}{l}\text { Yes }-21 \text { packs } \\
(3847 \mathrm{~mL}) \text { at } \\
\text { D6 on TPE }\end{array}$ & Yes & Yes-HUS \\
\hline 365 & $48 \mathrm{~h}^{a}$ & $2 \mathrm{~d}$ & Positive & $>60 / 12$ at $\mathrm{D} 4$ & $>5$ at D4 & $>60 / 25$ at D4 & 20 at D4 & 8.4 at D3 & Hematuria & $\begin{array}{l}\text { Yes-2 packs } \\
\text { at D2 }\end{array}$ & Yes & Yes-HUS \\
\hline 375 & $\begin{array}{l}4.5 \mathrm{~h} \text { at } \\
\text { medical } \\
\text { ward }\end{array}$ & $2 \mathrm{~d}$ & Positive & $22 / 12$ at D4 & 1.9 at $\mathrm{D} 4$ & $>60 / 25$ at $\mathrm{D} 4$ & 52 at D3 & 6.4 at D6 & No & $\begin{array}{l}\text { Yes-2 packs at } \\
\text { D1, D2 and } 19 \\
\text { packs }(3499 \mathrm{~mL}) \\
\text { at D5 on TPE }\end{array}$ & Yes & Yes-TTP \\
\hline 378 & $\begin{array}{l}4 \mathrm{~h} \text { at } \\
\text { medical } \\
\text { ward }\end{array}$ & $1 \mathrm{~d}$ & Positive & $13 / 12$ at $\mathrm{D} 1$ & 1.1 at D1 & $23 / 25$ at D1 & 236 at D2 & 10.1 at D2 & No & $\begin{array}{l}\text { Yes-3 packs } \\
\text { on D1 }\end{array}$ & No & No \\
\hline 419 & $\begin{array}{l}1 \mathrm{~h} \text { on } \\
\text { admission }\end{array}$ & $8 \mathrm{~d}$ & Positive & $>60 / 12$ at $\mathrm{D} 2$ & $>5$ at D2 & $>60 / 25$ at D2 & 129 at D2 & 7.5 at D2 & $\begin{array}{l}\text { Local bleeding, } \\
\text { microscopic } \\
\text { hematuria }\end{array}$ & $\begin{array}{l}\text { Yes-4 packs } \\
\text { at D2-D6 }\end{array}$ & Yes & No \\
\hline 420 & $\begin{array}{l}21 \mathrm{~h} \text { at } \\
\text { medical } \\
\text { ward }\end{array}$ & $1 \mathrm{~d}$ & Positive & $>60 / 12$ at D2 & $>5$ at $\mathrm{D} 2$ & $>60 / 25$ at $\mathrm{D} 2$ & 87 at D2 & 11.3 at D2 & No & No & No & No \\
\hline 461 & $\begin{array}{l}3.5 \mathrm{~h} \text { at } \\
\text { medical ward }\end{array}$ & $4 \mathrm{~d}$ & Positive & $>60 / 12$ at D1 & $>5$ at D1 & $>60 / 25$ at $\mathrm{D} 2$ & 95 at D3 & 6.9 at D5 & $\begin{array}{l}\text { Local bleeding, } \\
\text { hematuria, } \\
\text { bleeding from } \\
\text { wounds and } \\
\text { venipunctures }\end{array}$ & $\begin{array}{l}\text { Yes-4 packs } \\
\text { at D1-D4 }\end{array}$ & Yes & No \\
\hline
\end{tabular}


performed for patients who had deterioration in renal function: rising blood urea, serum creatinine and $\mathrm{K}^{+}$ level, anuria, oliguria or fluid overload features, and metabolic acidosis found in arterial blood gas analysis. In our study, hemodialysis was performed in 12 patients (40\%), ranging from 2 to 9 cycles; 2 (7\%) were transferred to National Hospital Colombo. Therapeutic plasma exchange (plasmapheresis) was done for patients who had TMA with persistent thrombocytopenia and severe microangiopathic hemolysis detected on serial blood pictures. Accordingly, 6 patients (21\%) underwent plasmapheresis, ranging from 1 to 3 cycles; of them, 2 $(12 \%)$ were in the proven group (S.No. 363 and 375) and $4(31 \%)$ were in the probable group (S.No. 364, 469,489 , and 498). Intramuscular tetanus toxoid was given when the patient was discharged. Ten patients $(33 \%)$ were followed up regularly in nephrology clinic.

\section{Discussion}

Among venomous snakes in Sri Lanka, hump-nosed vipers (Hypnale spp), ${ }^{2,-12,14-16,23,26}$ Russell's vipers (Daboia russelii), ${ }^{27}$ saw scaled vipers (Echis carinatus), ${ }^{28}$ and Sri Lankan Green pit vipers (Trimeresurus trigonocephalus) ${ }^{29}$ are known to cause VICC. The first authentic case of VICC after a hump-nosed viper bite in Sri Lanka was reported in 1994 in Central Province. The bite occurred in a 5-y-old boy who had coagulopathy that persisted for more than a week and was associated with gastrointestinal bleeding and $\mathrm{AKI} .{ }^{23}$

Snake venom serine proteases are the important coagulant enzymes found in $3 \%$ of $H$ hypnale venom ${ }^{30}$; they share homologous sequences with ancord, the best known major TLE in the venom of the Malayan pit viper (Calloselasma rhodostoma), the sister taxon of $H$ hypnale. Thus, it is believed that TLEs are the procoagulants in genus Hypnale venom. There are more than 67 TLEs in snake venom, most of which are zinc metalloproteinase. They consume fibrinogen rather than activating the clotting pathway. According to previous studies, VICC occurs in 3.5 to $39 \%$ of all hump-nosed viper bites, ${ }^{8-11,15}$ and $H$ hypnale accounts for $3.5 \%$ of the incidence. ${ }^{11}$ In our current study, VICC occurred in $6 \%$ of patients: $4 \%$ $(n=384)$ in the proven group and $11 \%(n=116)$ in the probable group.

There are only 2 previously reported cases of $H$ zara causing coagulopathy. ${ }^{2,11}$ In our cohort also, there was a proven case of VICC associated with TMA caused by $H$ zara bite. ${ }^{18}$ The most important complication of VICC in snake envenoming is spontaneous systemic bleeding, which occurs in $18 \%$ of Hypnale bites and includes hematemesis, gum bleeding, and hematuria. ${ }^{9}$ In our study, we observed 3\% $(n=16)$ of patients with systemic bleeding, 
Table 4. Hematological parameters of 13 patients in probable hump-nosed pit viper (Hypnale spp) envenoming

\begin{tabular}{|c|c|c|c|c|c|c|c|c|c|c|c|c|}
\hline $\begin{array}{l}\text { Patient } \\
\text { serial } \\
\text { no. }\end{array}$ & $\begin{array}{l}\text { Onset of } \\
\text { VICC after } \\
\text { snakebite }\end{array}$ & $\begin{array}{l}\text { End of } \\
\text { VICC } \\
\text { after } \\
\text { snakebite }\end{array}$ & WBCT20 & $\begin{array}{l}\text { Highest } \\
\text { PT (s) }\end{array}$ & $\begin{array}{l}\text { Highest } \\
\text { INR }\end{array}$ & $\begin{array}{l}\text { Highest } \\
\text { APTT (s) }\end{array}$ & $\begin{array}{l}\text { Lowest } \\
\text { platelet } \\
\text { count } \\
\left(\times 10^{3} \cdot \mu \mathrm{L}^{-1}\right)\end{array}$ & $\begin{array}{l}\text { Lowest } \\
\mathrm{Hb} \\
\left(\mathrm{g} \cdot \mathrm{dL}^{-1}\right)\end{array}$ & $\begin{array}{l}\text { Clinical } \\
\text { bleeding }\end{array}$ & $\begin{array}{l}\text { Administration } \\
\text { of FFP }\end{array}$ & МАHA & TMA \\
\hline 185 & $8 \mathrm{~h}$ at $\mathrm{LH}$ & $9 \mathrm{~d}$ & Positive & $>60 / 12$ at D3 & $>5$ at D3 & $\begin{array}{l}>60 / 25 \\
\text { at D8 }\end{array}$ & 86 at D2 & 9.1 at D3 & $\begin{array}{l}\text { Local and } \\
\text { venipuncture } \\
\text { bleeding }\end{array}$ & $\begin{array}{l}\text { Yes-2 packs at } \\
\text { D1-D4 }\end{array}$ & Yes & Yes \\
\hline 190 & $1 \mathrm{~h}$ at $\mathrm{LH}$ & $8 \mathrm{~h}$ & Positive & $>60 / 13$ at $\mathrm{D} 1$ & $>5$ at $\mathrm{D} 1$ & $\begin{array}{l}>60 / 30 \\
\text { at } \mathrm{D} 1\end{array}$ & 216 at D1 & 13 at D1 & No & No & No & No \\
\hline 364 & $4 \mathrm{~d}$ at $\mathrm{LH}^{a}$ & $1 \mathrm{~d}$ & Positive & $14 / 12$ at D1 & 1.4 at D1 & $35 / 25$ at D1 & 45 at D2 & 6.9 at D1 & $\begin{array}{l}\text { Subconjunctival } \\
\text { hemorrhages }\end{array}$ & $\begin{array}{l}\text { Yes }-14 \text { packs } \\
(4133 \mathrm{~mL}) \text { at } \mathrm{D} 5, \\
20 \text { packs at D6, } \\
17 \text { packs }(3170 \mathrm{~mL}) \\
\text { at } \mathrm{D} 7 \text { on TPE }\end{array}$ & Yes & Yes-HUS \\
\hline 368 & $3 \mathrm{~h}$ at $\mathrm{LH}$ & $1 \mathrm{~d}$ & Positive & $18.3 / 12$ at $\mathrm{D} 1$ & 1.5 at D1 & $30 / 25$ at D1 & 64 at D2 & 9.5 at D2 & No & No & Yes & Yes-HUS \\
\hline 393 & $\begin{array}{l}24 \mathrm{~h} \text { at } \\
\text { medical } \\
\text { ward }\end{array}$ & $2 d$ & Positive & $27 / 12$ at $\mathrm{D} 2$ & 2.3 at D2 & $50 / 25$ at D2 & 164 at D2 & 9.4 at D2 & Local bleeding & No & No & No \\
\hline 462 & $2 \mathrm{~h}$ at $\mathrm{LH}$ & $7 \mathrm{~d}$ & Positive & $>120 / 12$ at D3 & $>10$ at $\mathrm{D} 3$ & $\begin{array}{l}>60 / 25 \\
\text { at D3 }\end{array}$ & 94 at D2 & 6.7 at D12 & $\begin{array}{l}\text { Microscopic } \\
\text { hematuria }\end{array}$ & $\begin{array}{l}\text { Yes-2 packs at } \\
\text { D2-D5, D7, D11 }\end{array}$ & Yes & Yes-HUS \\
\hline 469 & $\begin{array}{l}12 \mathrm{~h} \text { on } \\
\text { admission }\end{array}$ & $3 \mathrm{~d}$ & Positive & $18 / 12$ at $\mathrm{D} 2$ & 1.6 at $\mathrm{D} 2$ & $26 / 25$ at D1 & 22 at D4 & 7.4 at D4 & No & $\begin{array}{l}\text { Yes }-3240 \mathrm{~mL} \text { at } \\
\mathrm{D} 5 \text { on TPE }\end{array}$ & Yes & Yes-HUS \\
\hline 474 & $\begin{array}{l}1.5 \mathrm{~h} \text { on } \\
\text { admission }\end{array}$ & $6 \mathrm{~d}$ & Positive & $>120 / 12$ at $\mathrm{D} 2$ & $>10$ at $\mathrm{D} 2$ & $\begin{array}{l}>120 / 25 \\
\text { at D3 }\end{array}$ & 175 at D2 & 9.7 at D4 & $\begin{array}{l}\text { Local and } \\
\text { venipuncture } \\
\text { bleeding }\end{array}$ & $\begin{array}{l}\text { Yes-3 packs at } \\
\text { D3-D4 }\end{array}$ & Yes & No \\
\hline 479 & $\begin{array}{l}24 \mathrm{~h} \text { on } \\
\text { admission }\end{array}$ & $3 d$ & Positive & $18 / 12$ at $\mathrm{D} 3$ & 1.5 at D3 & $28 / 25$ at D1 & 178 at D4 & 9.2 at D4 & No & $\begin{array}{l}\text { Yes-3 packs at } \\
\text { D3-D4 }\end{array}$ & No & No \\
\hline 484 & $\begin{array}{l}2.5 \mathrm{~h} \text { on } \\
\text { admission }\end{array}$ & $1 \mathrm{~d}$ & Positive & $18.2 / 12$ at D1 & 1.6 at D1 & $30 / 25$ at D1 & 205 at D2 & 10.9 at $\mathrm{D} 2$ & $\begin{array}{l}\text { Microscopic } \\
\text { hematuria }\end{array}$ & No & No & No \\
\hline 489 & $1 \mathrm{~h}$ at $\mathrm{LH}$ & $3 \mathrm{~d}$ & Positive & $24 / 12$ at D2 & 2.23 at $\mathrm{D} 2$ & $39 / 25$ at D2 & 44 at D3 & 8.6 at D8 & No & $\begin{array}{l}\text { Yes-3 packs at } \\
\text { D2-D4, } 12 \text { packs } \\
\text { at D5,D7 on TPE }\end{array}$ & Yes & Yes-HUS \\
\hline 493 & $\begin{array}{l}45 \text { min on } \\
\text { admission }\end{array}$ & $4 \mathrm{~d}$ & Positive & $>60 / 12$ at $\mathrm{D} 1$ & $>5$ at $\mathrm{D} 1$ & $>60 / 25$ at D1 & 203 at D2 & 11.7 at D3 & No & $\begin{array}{l}\text { Yes-3 packs at } \\
\text { D2-D3 }\end{array}$ & No & No \\
\hline 498 & 3 days at $\mathrm{LH}^{2}$ & $2 \mathrm{~d}$ & Positive & $>60 / 12$ at D2 & $>5$ at $\mathrm{D} 2$ & $\begin{array}{l}>120 / 25 \\
\text { at D2 }\end{array}$ & 44 at D3 & 6.7 at D3 & No & $\begin{array}{l}\text { Yes }-13 \text { packs } \\
(3320 \mathrm{~mL}) \text { at } \\
\text { D3 on TPE }\end{array}$ & Yes & Yes-HUS \\
\hline
\end{tabular}

APTT, activated partial thromboplastin time; FFP, fresh frozen plasma; Hb, hemoglobin; HUS, hemolytic uremic syndrome; INR, international normalized ratio; LH, local hospital; MAHA, microangiopathic hemolytic anemia; PT, prothrombin time; TMA, thrombotic microangiopathy;VICC, venom induced consumption coagulopathy; WBCT20, 20-min whole blood clotting test.

${ }^{a}$ Late presentation to the medical facility after having native treatments. 


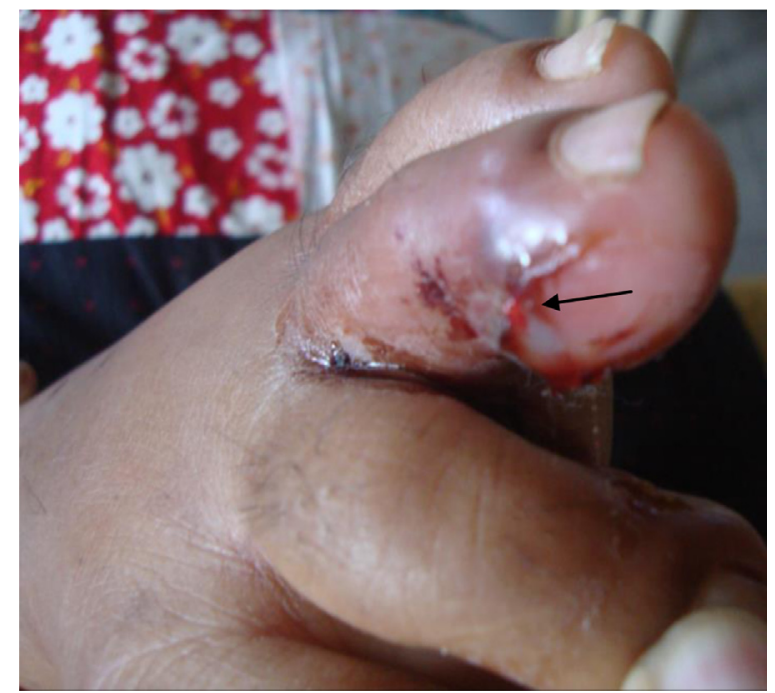

Figure 2. Local bleeding in left third toe (pointed arrow) on admission in patient S.No. 53 in the proven group.

including venipuncture bleeding, generalized ecchymoses (bleeding into the skin), gum bleeding, rectal bleeding, and pulmonary and subconjunctival hemorrhage. Of these, subconjunctival hemorrhage has not previously been reported. TMA is one of the systemic features of envenoming in Hypnale bites. It includes the triad of AKI, microangiopathic hemolytic anaemia, and thrombocytopenia. It is usually associated with VICC, ${ }^{31}$ and in our current study, there were 13 patients (43\%) with TMA in both proven and probable groups. However, it may also occur without coagulopathy in Hypnale envenoming. ${ }^{13}$

Because antivenoms are not currently available for hump-nosed viper envenoming, FFP therapy is the mainstay of treatment in these patients. Thus, 20 (67\%) were

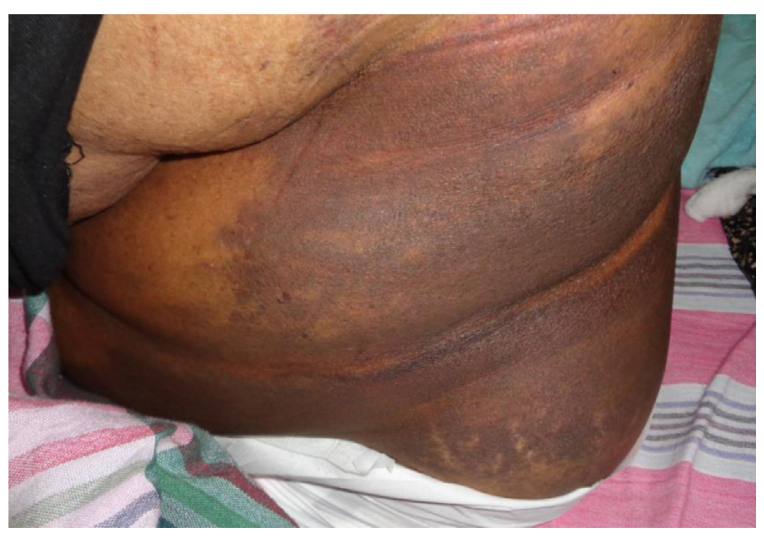

Figure 3. Generalized ecchymoses on day 7 of $H$ hypnale bite in patient S.No. 293. administered FFP at the time of diagnosis of VICC, and treatment continued for more than $1 \mathrm{~d}$ in some patients (Tables 3 and 4). However, the PT/INR and APTT of some patients $(n=9 ; 45 \%)$ did not undergo early correction despite FFP administration. In S.No. 419 patient, FFP was given from Day 2 to Day 6 because she had persistent unclotted blood detected on WBCT20 and associated with prolonged PT/INR and APTT. Her PT/INR and APTT did not improve until Day 8. In S.No. 462 patient (probable group), FFP was administered from Day 2 to Day 5, Day 7, and Day 11 because the patient had persistent incoagulable blood associated with high PT/INR (Table 4). However, the patient also did not improve. S.No. 474 patient (probable group) had unclotted blood on WBCT20 on admission from $1.5 \mathrm{~h}$ to 6 days from the snakebite. Despite receiving 3 packs of FFP on Days 3 to 4, her clotting profile was elevated throughout, and rotational thromboelastometry (done on Day 4 after FFP) showed a very low level of fibrinogen and clotting factors. Furthermore, patient S.No. 500 had a severe form of VICC associated with persistent systemic bleeding (hematuria, bleeding gums, rectum, lungs, and venipunctures). The patient received FFP and cryoprecipitate on Days 2 and 3 of snakebite, but his INR and APTT were persistently high and associated with positive WBCT20; the patient died on Day 4 as a result of severe systemic bleeding (pulmonary hemorrhage) associated with coagulopathy. ${ }^{25}$ Thus, it was observed that in some patients, VICC caused by hump-nosed viper bites is not corrected with FFP therapy. However, the benefits of FFP in treating VICC are doubtful in envenomings by snakes with procoagulant venoms, such as hump-nosed vipers, ${ }^{16}$ Russell's vipers, ${ }^{32}$ and Australian elapids. ${ }^{33}$ Theoretically, clotting factor replacement (FFP and cryoprecipitate) should correct coagulopathy in the absence of venom-induced clotting factor consumption. In Hypnale envenoming, however, in the absence of antivenom, persistent ongoing clotting factor consumption occurs, and factor replacement may worsen the state of coagulopathy because more substrate will be available for the procoagulant toxins to activate and elevate the levels of degradation products. This may accelerate the hyperfibrinolytic state and increase the risk of bleeding. ${ }^{34,35}$ On the other hand, fatalities may occur with FFP therapy in management of snakebites owing to reactions for blood products. ${ }^{32}$ Therefore, factor replacement may cause more harm than benefit in hump-nosed viper bites. Studies have shown, however, that FFP is beneficial when given after provision of appropriate antivenom; in Russell's viper bites, FFP $8 \mathrm{~h}$ after antivenom administration was proven to be benificial. ${ }^{32}$ 

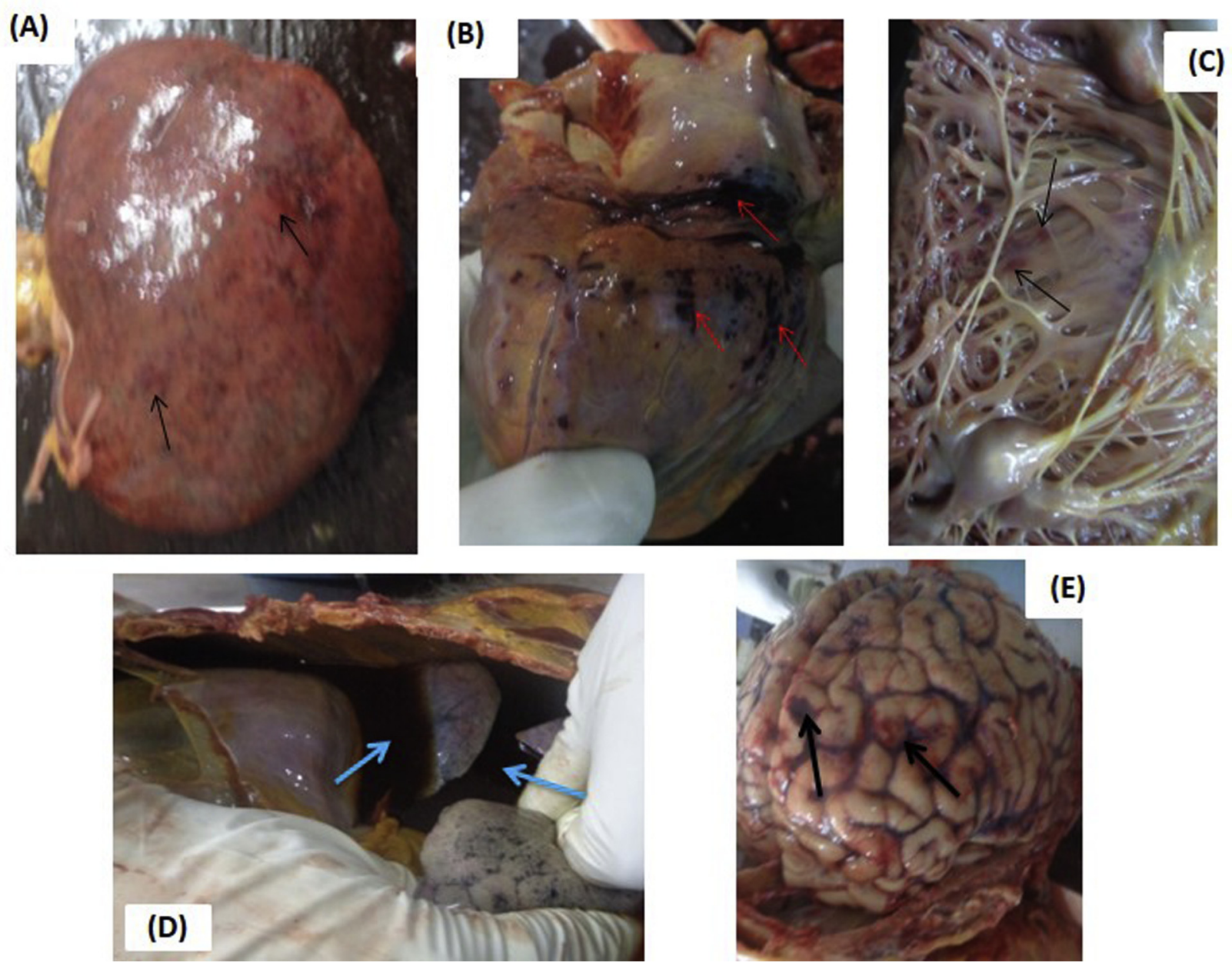

Figure 4. Macroscopic bleeding manifestations found in postmortem examination of patient S.No. 500, who died of severe venom-induced consumption coagulopathy after proven $H$ hypnale bite. (A) Petechial hemorrhages in left kidney (pointed arrows). (B) Pericardial hemorrhages (pointed arrows). (C) Endocardial hemorrhages (pointed arrows). (D) Bleeding into thoracic cavity (pointed arrows). (E) Cerebral hemorrhages (pointed arrows).

Laboratory diagnosis is the key step in treating VICC; therefore, appropriate coagulation tests should be used for these patients. WBCT20 is the widely used simple bedside test for detecting snakebite coagulopathy. In clinical practice, however, WBCT20 has low sensitivity for detecting VICC. ${ }^{36}$ Even though a standard WBCT20 is relatively sensitive, it still misses $20 \%$ of cases with coagulopathy requiring antivenom. ${ }^{37}$ In low-income countries where snakebites are common, the best option is WBCT20. ${ }^{38}$ However, the combination of PT (INR) and APTT is a reliable and cost-effective end point for treating VICC. ${ }^{39}$ In our present study, all patients had incoaguable blood except 1 (S.No. 363) whose WBCT20 had clotted blood but his PT/INR and PT/APTT were high. Intracranial and pulmonary hemorrhages are the worst complications and have fatal outcomes in VICC. However, they may occur after humpnosed viper bites, too. In our study, there was a death due to pulmonary hemorrhage and other systemic bleeding including intracranial hemorrhage associated with severe VICC in a proven $H$ hypnale bite. ${ }^{25}$

\section{Conclusions}

Treating VICC is a challenge to clinicians in a state where antivenom is not available for Hypnale envenoming in Sri Lanka and also with the doubtful efficacy of FFP therapy. Even with antivenom therapy, pulmonary hemorrhages have fatal outcomes. ${ }^{40}$ Therefore, it is appropriate to develop an antivenom for Hypnale venom to counteract severe systemic effects. 

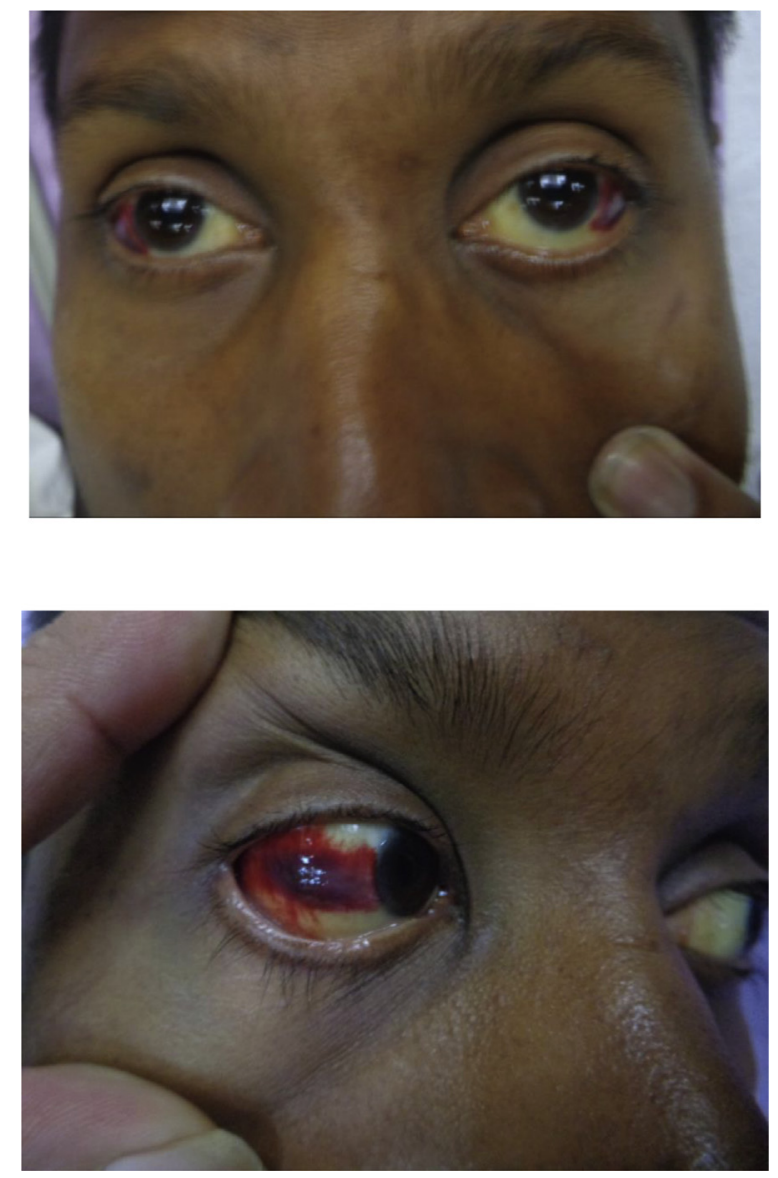

Figure 5. Bilateral subconjuctival haemorrhages on day 6 of hump-nosed viper bite in S.No. 364 patient in the probable group.

Acknowledgments: We are grateful to the staff of medical wards and ICU and the consultant physicians (Dr. N Sritharan, Dr. AGH Sugathapala, Dr. KDM Kumarasinghe, Dr. K. Jeganadan, and Dr. L. Abeywardhana) in THR-Sri Lanka. Dr. Radha Jayathunga and Dr. WDP Vidyarathna (consultant haematologists, THR) are acknowledged for the interpretation of peripheral blood pictures. Dr. CE Ranasinghe (JMO-Teaching Hospital, Ratnapura) was acknowledged for the interpretation of postmortem findings.

Author Contributions: Involvement of patients' management and literature search (RMMKNR, PEANR); clinical assessment, snake handling and morphological feature identification (RMMKNR); analysis and interpretation of data (RMMKNR, SAMK, PEANR), drafting of the manuscript and writing of case histories (RMMKNR, SAMK, PEANR); review and approval of the final manuscript (RMMKNR, SAMK, PEANR).

Financial/Material Support: None.

Disclosures: None.

\section{References}

1. WHO Expert Committee on Biological Standardization. WHO Guidelines for the production control and regulation of snake antivenom immunoglobulins. WHO Technical Report Series. Geneva, Switzerland: WHO; 2010.

2. Maduwage K, Kularatne K, Wazil A, Gawarammana I. Coagulopthy, acute kidney injury and death following Hypnale zara envenoming: the first case report from Sri Lanka. Toxicon. 2011;58(8):641-3.

3. Namal Rathnayaka RMMK, Ranathunga PEAN. Acute kidney injury which leads to chronic kidney disease and death following hump-nosed pit viper (Genus: Hypnale) envenoming. J Ratnapura Clin Soc. 2016;1:40-2.

4. Namal Rathnayaka RMMK, Nishanthi Ranathunga PEA, Ranaweera J, Jayasekara K, Kularatne SAM. Cardiac arrest and atrial fibrillation following hump-nosed pit viper (Hypnale hypnale) envenoming. Toxicon. 2018;148:33-9.

5. Kasturiratne A, Pathmeswaran A, Fonseka MM, Lalloo DC, Brooker S, de Silva HJ. Estimates of disease burden due to land-snakebite in Sri Lankan hospitals. Southeast Asian J Trop Med Pub Health. 2005;36(3):733-40.

6. Kasturiratne A, Wickremasinghe AR, de Silva N, Gunawardena NK, Pathmeswaran A, Premaratna R, et al. The global burden of snakebite: a literature analysis and modeling based on regional estimates of envenoming and deaths. PLoS Med. 2008;5(11):e218.

7. Maduwage K, Silva A, Manamendra-Arachchi K, Pethiyagoda R. A taxonomic revision of the South Asian hump-nosed pit vipers (Squamata: Viperidae: Hypnale). Zootaxa. 2009;2232(1):1-28.

8. Wijewantha HS, Sellahewa KH. Hump nosed viper bite in Sri Lanka-descriptive observational study of 1543 cases. Asian Pac J Trop Med. 2010;3(11):902-5.

9. Ariaratnam CA, Thuraisingam V, Kularatne SA, Sheriff MH, Theakston RD, de Silva A, et al. Frequent and potentially fatal envenoming by hump-nosed pit vipers (Hypnale hypnale and H. nepa) in Sri Lanka: lack of effective antivenom. Trans $R$ Soc Trop Med Hyg. 2008;102(11):1120-6.

10. Maduwage K, Isbister GK, Silva A, Bowatta S, Mendis S, Gawarammana I. Epidemiology and clinical effects of hump-nosed pit viper (Genus: Hypnale) envenoming in Sri Lanka. Toxicon. 2013;61:11-5.

11. Namal Rathnayaka RMMK, Kularatne SAM, Ranathunga PEAN, Rajapakse RPVJ, Ranasinghe JGS. Species specific clinical manifestations following Hump-nosed pit viper (Genus: Hypnale) envenoming in Sri Lanka. In: Sri Lanka Medical Association $130^{\text {th }}$ Anniversary International Medical Congress, Colombo 13-16 July 2017. Ceylon Med J. 2017;62(Suppl. 1):97.

12. Kularatne SAM, Ratnatunga N. Severe systemic effects of Merrem's hump-nosed viper bite. Ceylon Med J. 1999;44(4):169-70.

13. Namal Rathnayaka RMMK, Ranathunga PEAN, Kularatne SAM. Kidney injury following envenoming by hump-nosed pit viper (Genus: Hypnale) in Sri Lanka: proven and probable cases. Trans R Soc Trop Med Hyg. 2019;113(3): 131-42.

14. Premawardena AP, Seneviratne SL, Jayanthi S, Gunatilake SB, de Silva HJ. Coagulopathy and fibrinolysis following the bite of a hump-nosed viper (Hypnale hypnale). Trans R Soc Trop Med Hyg. 1996;90(3):293.

15. Premawardena AP, Seneviratne SL, Gunatilake SB, de Silva HJ. Excessive fibrinolysis: the coagulopathy following 
Merrm's Hump-nosed viper (Hypnale hypnale) bites. Am J Trop Med Hyg. 1998;58(6):821-3.

16. Kumara H, Seneviratne N, Jayaratne DS, Siribaddana S, Isbister GK, Silva A. Severe coagulopathy in Merrem's hump-nosed pit viper (Hypnale hypnale) envenoming unresponsive to fresh frozen plasma: a case report. Toxicon. 2019;163:19-22.

17. Namal Rathnayaka RMMK, Nishanthi Ranathunga PEA, Kularatne SAM. Thrombotic microangiopathy, hemolytic uremic syndrome and thrombotic thrombocytopenic purpura following hump-nosed pit viper (Genus: Hypnale) envenoming in Sri Lanka. Wilderness Environ Med. 2019;30(1):66-78.

18. Namal Rathnayaka RMMK, Nishanthi Ranathunga PEA, Kularatne SAM. Thrombotic microangiopathy following Hypnale zara (hump-nosed pit viper) envenoming: the first known case report from Sri Lanka. Wilderness Environ Med. 2020;31(1):71-7.

19. Jeevagan V, Chang T, Gnanathasan AC. Acute ischemic stroke following Hump-nosed viper envenoming; first authenticated case. Thromb J. 2012;10(1):21.

20. Thillainathan S, Priyangika D, Marasinghe I, Kanapathippillai K, Premawansa G. Rare cardiac sequelae of a hump nosed viper bite. BMC Res Notes. 2015;8:437.

21. Namal Rathnayaka RMMK, Kularatne SAM, Ranathunga PEAN, Kumarasinghe KDM, Rajapakshe RPVJ, Ranasinghe JGS. Prolonged coagulopathy, ecchymoses and microangipathic haemolytic anaemia following hump-nosed pit viper (Hypnale hypnale) bite in Sri Lanka. Wilderness Environ Med. 2017;28(3):253-8.

22. Isbister GK. Procoagulant snake toxins: laboratory studies, diagnosis, and understanding snakebite coagulopathy. Semin Thromb Hemost. 2009;35(1):93-103.

23. de Silva A, Wijekoon AS, Jayasena L, Abeysekera CK, Bao CX, Hutton RA, et al. Haemostatic dysfunction and acute renal failure following envenoming by Merrem's Hump-nosed viper (Hypnale hypnale) in Sri Lanka: first authenticated case. Trans R Soc Trop Med Hyg. 1994;88(2): 209-12.

24. Maduwage K, Scorgie FE, Silva A, Shahmy S, Mohamed F, Abeysinghe $\mathrm{C}$, et al. Hump-nosed pit viper (Hypnale hypnale) envenoming causes mild coagulopathy with incomplete clotting factor consumption. Clin Toxicol (Phila). 2013;51(7): 527-31.

25. Namal Rathnayaka RMMK, Nishanthi Ranathunga PEA, Kularatne SAM. Systemic bleeding including pulmonary haemorrhage following hump-nosed pit viper (Hypnale hypnale) envenoming: a case report from Sri Lanka. Toxicon. 2019;170:21-8.

26. Dharmaratne L, Gunawardena U. Generalized bleeding tendency and acute renal failure following Merrem's Humpnosed viper bite. J Ceylon College Physicians. 1988-89;2122:37-42.

27. Kularatne SAM. Epidemiology and clinical picture of the Russell's viper (Daboia russelii russelii) bite in Anuradhapura, Sri Lanka: a prospective study of 336 cases. Southeast Asian J Trop Med Public Health. 2003;34(4):855-62.
28. Kularatne SAM, Sivansuthan S, Medagedara SC, Maduwage K, de Silva A. Revisiting saw-scaled viper (Echis carinatus) bites in the Jaffna Peninsula of Sri Lanka: distribution, epidemiology and clinical manifestations. Trans R Soc Trop Med Hyg. 2011;105(10):591-7.

29. Namal Rathnayaka RMMK, Ranathunga PEAN, Kularatne SAM. Epidemiology and clinical features of Green pit viper (Trimeresurus trigonocephalus) envenoming in Sri Lanka. Toxicon. 2017;137:99-105.

30. Tan CH, Tan NH, Sim SM, Fung SY, Gnanathasan CA. Proteomic investigation of Sri Lankan hump-nosed pit viper (Hypnale hypnale) venom. Toxicon. 2015;93:164-70.

31. Isbister GK. Snakebite doesn't cause disseminated intravascular coagulation: coagulopathy and thrombotic microangiopathy in snake envenoming. Semin Thromb Hemost. 2010;36(4):444-51.

32. Isbister GK, Jayamanne S, Mohamed F, Dawson AH, Maduwage K, Gawarammana I, et al. A randomized controlled trial of fresh frozen plasma for coagulopathy in Russell's viper (Daboia russelii) envenoming. J Thromb Haemost. 2017;15(4):645-54.

33. Isbister GK, Buckley NA, Page CB, Scorgie FE, Lincz LF, Seldon M, et al. A randomized controlled trial of fresh frozen plasma for treating venom-induced consumption coagulopathy in cases of Australian snakebite (ASP-18). J Thromb Haemost. 2013;11(7):1310-8.

34. Jelinek GA, Smith A, Lynch D, Celenza A, Irving I, Michalopoulos N, et al. The effect of adjunctive fresh frozen plasma administration on coagulation parameters and survival in a canine model of antivenom-treated brown snake envenoming. Anaesth Intensive Care. 2005;33(1): 36-40.

35. White J. Snake venoms and coagulopathy. Toxicon. 2005;45(8):951-67.

36. Isbister GK, Maduwage K, Shahmy S, Mohamed F, Abeysinghe C, Karunathilake H, et al. Diagnostic 20-min whole blood clotting test in Russell's viper envenoming delays antivenom administration. QJM. 2013;106(10): 925-32.

37. Ratnayake I, Shihana F, Dissanayake DM, Buckley NA, Maduwage K, Isbister GK. Performance of the 20-minute whole blood clotting test in detecting venom induced consumption coagulopathy from Russell's viper (Daboia russelii) bites. Thromb Haemost. 2017;117(3):500-7.

38. Gaus DP, Herrera DF, Troya CJ, Guevara AH. Management of snakebite and systemic envenomationin rural Ecuador using the 20-minute whole blood clotting test. Wilderness Environ Med. 2013;24(4):345-50.

39. Isbister GK, Williams V, Brown SGA, White J, Currie BJ. Clinically applicable laboratory end-points for treating snakebite coagulopathy. Pathology. 2006;38(6): 568-72.

40. Palangasinghe DR, Weerakkody RM, Dalpatadu CG, Gnanathasan CA. A fatal outcome due to pulmonary hemorrhage following Russell's viper bite. Saudi Med J. 2015;36(5):634-7. 